\title{
The use of hydrodynamic disintegration as a means to improve anaerobic digestion of activated sludge
}

\author{
A Machnicka*, K Grübel and J Suschka \\ University of Bielsko-Biala, 43-300 Bielsko-Biala, ul Willowa 2, Poland
}

\begin{abstract}
Disintegration by hydrodynamic cavitation has a positive effect on the degree and rate of sludge anaerobic digestion. By applying hydrodynamic disintegration the lysis of cells occurs in minutes instead of days. The intracellular and extracellular components are set free and are immediately available for biological degradation which leads to an improvement of the subsequent anaerobic process. Hydrodynamic disintegration of the activated sludge results in organic matter and a polymer transfer from the solid phase to the liquid phase, and an increase in COD value of $284 \mathrm{mg} \cdot \ell^{-1}$ was observed, i.e. from $42 \mathrm{mg} \cdot \ell^{-1}$ to $326 \mathrm{mg} \cdot \ell^{-1}$. In addition the degree of disintegration changed from $14 \%$ after $15 \mathrm{~min}$ disintegration to $54 \%$ after $90 \mathrm{~min}$ of disintegration.

A disruption of bacterial cells by hydrodynamic cavitation has a positive effect on the degree and rate of excess sludge anaerobic digestion. The cells of the activated sludge micro-organisms rupture and addition to the digestion process leads to increased biogas production. The hydrodynamic disintegration of activated sludge leads to a higher degree of degradation and higher biogas production. Adding the disintegrated sludge (10\%, $20 \%$ and $30 \%$ of volume) to fermentation processes resulted in an improvement in biogas production of about $22 \%, 95 \%$ and $131 \%$ respectively.
\end{abstract}

Keywords: anaerobic digestion, hydrodynamic disintegrations, cavitations, biogas

\section{Introduction}

The aim of wastewater treatment is to mineralise organic matter and enhance nutrient removal. Anaerobic digestion is a common method for activated sludge stabilisation resulting in the reduction of sludge volatile matter and the production of biogas. Anaerobic degradation of biomass is considered to follow a sequence of four phases: hydrolysis, acidogenesis, acetogenesis and methanogenesis. The slow degradation rate of activated sludge in the anaerobic digestion process is due to the rate-limiting step of sludge hydrolysis. Therefore, the disintegration pretreatment of an activated sludge process using physical (thermal), chemical (using e.g. acids), mechanical (ball mill, ultrasonic), oxidation (ozone and hydrogen peroxide), or biological (using enzymes) treatment processes, can improve the subsequent anaerobic digestion (Burgess and Pletschke, 2008; Hiraoka et al., 1984; Kennedy et al., 2007; Muller, 2000; Tiechm et al., 1997; Wang et al., 2004). Although the methods are different, the aim of all of them is partial or complete bacterial cell rupture, i.e. destruction of the cell wall and release of organic substances present inside the cells to the liquid phase. Disintegration by hydrodynamic cavitation has a positive effect on the degree and rate of sludge anaerobic digestion.

Hydrodynamic cavitation results in the formation of cavities (bubbles) filled with vapour - gas mixture inside the flowing liquid, or at the boundary of a constrictive device due to rapid local pressure drop. Subsequently, downstream of the constriction (valve or nozzle) the pressure recovers, causing

\footnotetext{
* To whom all correspondence should be addressed.

诲 +48 33 8279131; fax: +48 33 8279101;

e-mail: amachnicka@ath.bielsko.pl

Received 15 September 2008; accepted in revised form 17 December 2008.
}

cavities to collapse. The collapse of the cavitation bubbles is defined as an implosion the associated forces cause mechanical and physicochemical effects. The physical effects include the production of shear forces and shock waves, whereas the chemical effects result in the generation of radicals, e.g. formation of reactive hydrogen atoms and hydroxyl radicals which recombine to form hydrogen peroxide (Senthilkumar et al., 2000; Senthilkumar and Pendit; 1999; Vichare et al., 2000,). Hydrodynamic disintegration can activate the biological hydrolysis process and therefore significantly increase the biogas production in anaerobic stabilisation.

The new concept described in this paper is based on the combined process of activated sludge hydrodynamic disintegration prior to anaerobic digestion, with the aim of achieving improved sludge digestion.

\section{Materials and methods}

Activated sludge samples were taken from a full-scale municipal sewage treatment plant operated according to the EBNR (enhanced biological nutrients removal) process.

\section{The hydrodynamic disintegration}

Mechanical disintegration of $25 \ell$ aliquots of activated sludge was executed in the process of hydrodynamic cavitation; the experimental set-up consisted of a 12 bar Author: please convert to SI (Pascal or $\mathrm{N} \cdot \mathrm{m}^{-2}$ ) please pressure pump, rating $1.1 \mathrm{~kW}$, output $500 \ell \cdot h^{-1}$, which recirculated sludge from a container, through a $1.2 \mathrm{~mm}$ nozzle; $3 \mathrm{~min}$ were required to force $25 \ell$ of sludge through the nozzle. The scheme of the experimental setup is given in Fig. 1. Disintegration was carried out over periods of 15, 30 and $60 \mathrm{~min}$. COD was measured for samples before and after each period of disintegration. 


\section{The physico-chemical analysis}

Chemical oxygen demand (COD) value was determined for samples before and after each time of disintegration according to Standard Methods (1995) (procedures, using standard potassium dichromate solution.

Volatile suspended solids (VSS) concentration was determined according to Tchobanoglous et al. (2002).

Biogas/methane was determined after fermentation processes according to Standard Methods (1995) procedures, using Orsat-type gas-analysis apparatus.

\section{The degree of disintegration}

In order to obtain a quantitative measure of the effects of disintegration, Kunz and Wagner (1994) have proposed a coefficient which they called the degree of disintegration (DD). Later this coefficient was modified by Müller (1996).

In this paper the degree of sludge disintegration was determined according to that given by Müller (1996) as follows:

$$
\mathrm{DD}=\left[\left(\mathrm{COD}_{1}-\mathrm{COD}_{2}\right) /\left(\mathrm{COD}_{3}-\mathrm{COD}_{2}\right)\right] \cdot 100(\%)
$$

where:

$D D$ is degree of disintegration

$C O D$ is the COD of the liquid phase of the disintegrated sample

$\mathrm{COD}_{2}$ is the COD of the original sample

$\mathrm{COD}_{3}$ is the value after chemical disintegration

Chemical disintegration was done in this case by treating the sludge samples for $10 \mathrm{~min}$ at $90^{\circ} \mathrm{C}$ after adding $\mathrm{NaOH}, 1 \mathrm{M}$, in a ratio of 1:2. Centrifugation in all cases was done for $10 \mathrm{~min}$ at $30000 \mathrm{~g}$.

\section{The fermentation experiments}

The anaerobic digestion experiments were performed in six glass fermenters $(25 \ell)$ operated in parallel at a temperature of $30{ }^{\circ} \mathrm{C}$. Residence time was $22 \mathrm{~d}$. The production of biogas was measured daily. Different rates of raw and disintegrated activated sludge were applied:

- Fermenter 1 - was fed with raw activated sludge (symbol: $\mathrm{S}$ ), (as control; volatile solids $5.64 \mathrm{~g} \cdot \ell^{-1}$ )

- Fermenter 2 - was fed with raw activated sludge (90\% volume of fermenter), and surplus activated sludge after hydrodynamic disintegration (10\% volume of fermenter), (symbol: $90 \% \mathrm{~S}+10 \% \mathrm{DS}$ ) (volatile solids $5.60 \mathrm{~g} \cdot \ell^{-1}$ )

- Fermenter 3 - was fed with raw activated sludge ( $80 \%$ volume of fermenter), and surplus activated sludge after hydrodynamic disintegration $(20 \%$ volume of fermenter), (symbol: $80 \% \mathrm{~S}+20 \% \mathrm{DS}$ ) (volatile solids $\left.5.48 \mathrm{~g} \cdot \ell^{-1}\right)$

- Fermenter 4 - was fed with raw activated sludge ( $70 \%$ volume of fermenter), and activated sludge after hydrodynamic disintegration (30\% volume of fermenter), (symbol: $70 \% \mathrm{~S}+30 \% \mathrm{DS}$ ) (volatile solids $\left.5.29 \mathrm{~g} \cdot \ell^{-1}\right)$

The aim of carrying out the experiment of sludge digestion was to show the possibilities to improve and accelerate the anaerobic process. A scheme of the experimental configuration is shown in Fig. 1.

The investigations presented here were performed in 10 stages, and arithmetic average and standard deviation were established. Standard deviation was determined according to estimator of highest credibility in STATISTICA 6.0.

\section{Results and discussions}

The activated sludge flocs are agglomerates of bacteria maintained together due to the presence of exopolymers (EPS). These polymers are composed of sugars, amino acids and uronic acids. Adsorptive properties of exopolymers have been well documented especially with respect to biosorption of pollutants. Biosorption studies regarding biological wastewater treatment have focused on both the biosorption of hazardous organic pollutants and COD onto aerobic and anaerobic biomass (Esparza-Soto and Westerhoff, 2003; Cloete and Oosthuizen, 2001; Guellil et al., 2001). Disintegration of activated sludge flocs means destruction of EPS and bacteria dispersion as well as partial or complete bacterial cell destruction. As a result, release of intracellular organic matter and enzymes present in cells' cytosol as well as destruction of EPS results in increased dissolved organic matter concentration in the liquid.

The direct effect of the release of intracellular and exocellular organic matter can therefore be measured as soluble COD increase.

Already after 15 min of mechanical activated sludge floc disintegration a COD increase in the filtrate (filter paper) of 94 $\mathrm{mg} \cdot \ell^{-1}$ (from 42 tol36 $\mathrm{mg} \cdot \ell^{-1}$ ) could be observed, which is an increase of more than double. With increasing disintegration time a further increase in soluble COD occurs (Fig. 2).

Hydrodynamic cavitation treatment of activated sludge caused disruption of floc structure and resulted in a different degree of disintegration (DD). The effect of hydrodynamic cavitation time on sludge disintegration was studied. The results of the experiments are presented in Fig. 3.

Within the range of explored time, between 15 min and 90 min, the degree of disintegration increased most rapidly in the first $30 \mathrm{~min}$. The achieved degree of sludge disintegration was about $38 \%$. The efficiency of sludge disintegration increased further for a prolonged time (Fig. 3).

Hydrodynamic disintegration accelerates the biological degradation of sludge. The cell liquid contains components, which upon being released, can be easily assimilated. The released organic substances (expressed here as COD) as a result of activated sludge floc disintegration, lead to a substantial increase of biogas production in the subsequent anaerobic sludge digestion process (Fig. 4).

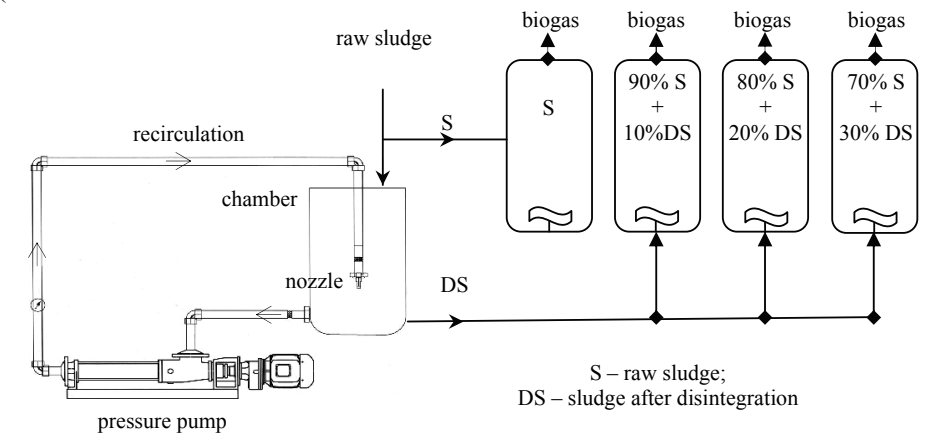

Figure 1

Scheme of the experimental configuration 


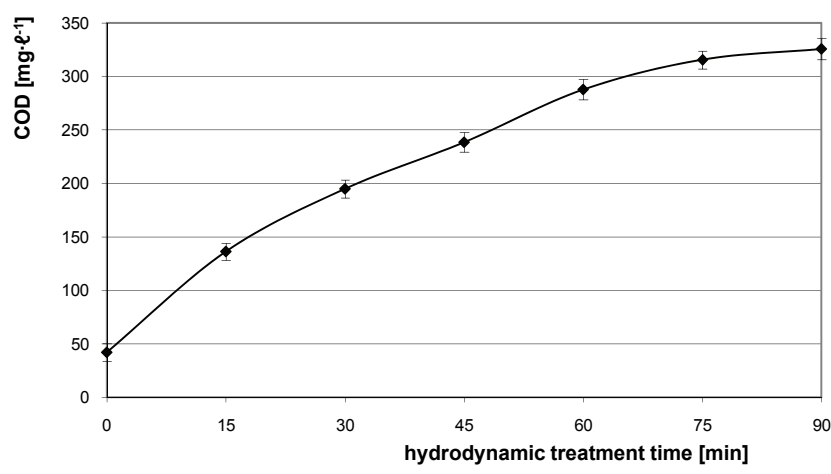

Figure 2

Increase of $C O D$ in the sludge supernatant after hydrodynamic treatment of activated sludge

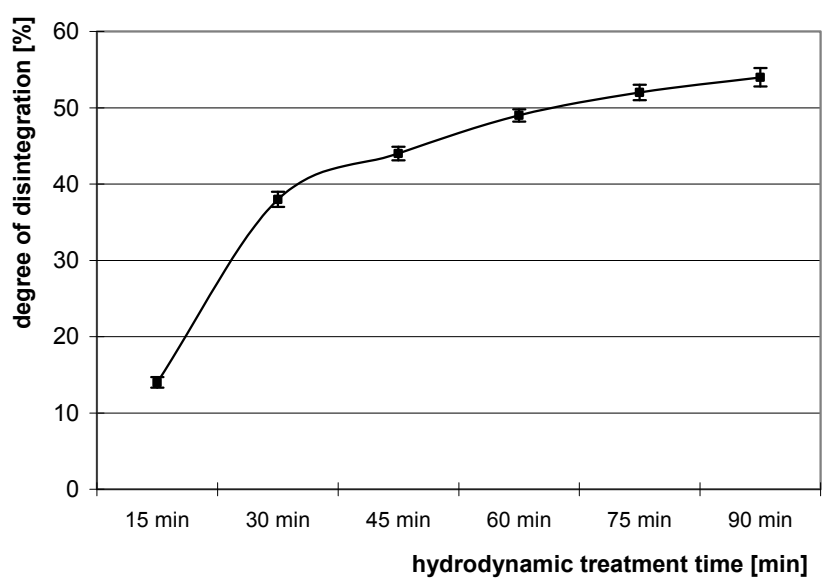

Figure 3

Degree of activated sludge disintegration

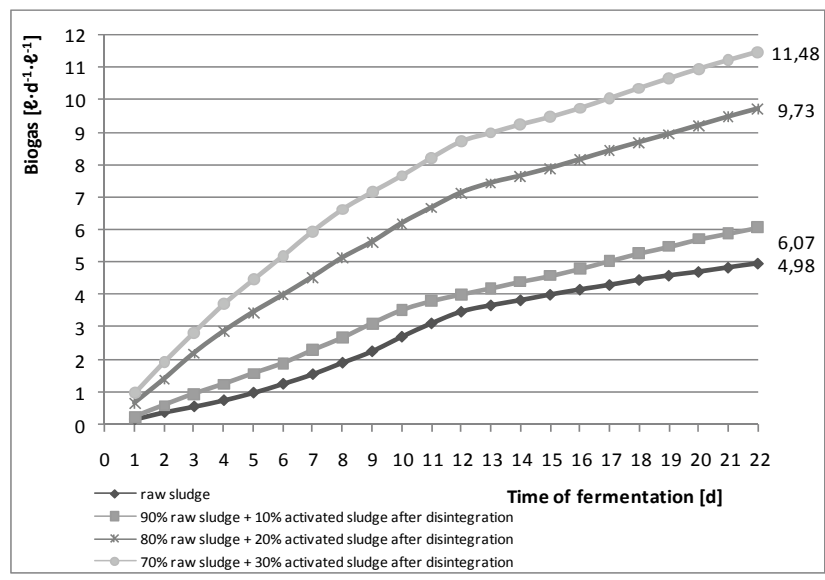

Figure 4

Production of biogas during fermentation

Significantly higher amounts of biogas were produced in the fermenters fed with disintegrated activated sludge $(10 \%$, $20 \%$ or $30 \%$ volume of fermenter). The gas production during sludge digestion depends on volatile solids, degree of disintegration (expressed as COD) and fermentation time. Volatile activated sludge solids ranged between $63 \%$ and $65 \%$.

The organic matter transferred by hydrodynamic treatment from the sludge solids into the liquid phase was readily biodegradable. Activated sludge consists mainly of heterotrophic bacteria. The gradual break-up of the bacterial cell walls limits the degradation process. By applying hydrodynamic disintegration the lysis of cells occurs in minutes instead of days. The intracellular and extracellular components are set free and are immediately available for biological degradation which leads to an improvement of the subsequent anaerobic process. In Fig. 4, this is shown by comparing the increase of biogas production in the anaerobic digestion, post hydrodynamic disintegration.

A calculation of energy consumption and cost shows that the hydrodynamic disintegration process is economically viable. The surplus gas can be used for power and heat production. This energy yield can be used for the hydrodynamic disintegration of activated sludge. The reduced cost for the sludge disposal, enhanced fermentation rates and acceleration of biogas production should lead to the practical use of hydrodynamic disintegration as a new technology.

\section{Conclusions}

The experiments have clearly demonstrated that hydrodynamic disintegration is a suitable method to destroy activated sludge micro-organisms. In this study, addition of hydrodynamic disintegrated activated sludge was examined in order to improve the anaerobic digestion process. The most important conclusions are:

- The hydrodynamic disintegration of activated sludge destroys the floc structure of sludge and ruptures the cells of the micro-organisms. As a result of sludge disintegration, organic matter is transferred from the sludge solids phase into the liquid phase (expressed as COD). COD increased from $42 \mathrm{mg} \cdot \ell^{-1}$ to $326 \mathrm{mg} \cdot \ell^{-1}$ in direct proportion with the time needed for disintegration.

- The hydrodynamic disintegration of activated sludge leads to a higher degree of degradation and higher biogas production. Addition of disintegrated sludge $(10 \%, 20 \%$ and $30 \%$ of volume) to the anaerobic digestion stage resulted in increased biogas production, about 22\%, 95\% and $131 \%$ respectively.

\section{References}

BURGESS JE and PLETSCHKE BI (2008) Hydrolytic enzymes in sewage sludge treatment: A mini-review. Water SA 34 (3) 343-349. http://www.wrc.org.za/downloads/watersa/2008/July/2209.pdf.

CLOETE TE and OOSTHUIZEN DJ (2001) The role of extracellular exopolymers in the removal of phosphorous from activated sludge. Water Res. 35 (15) 3595-3598.

STANDARD METHODS (1995) Eaton AD, Clesceri LS and Greenberg AE (eds.) Standard Methods for the Examination of Water and Wastewater $\left(19^{\text {th }}\right.$ edn.) American Public Health Association, Washington.

ESPARZA-SOTO M and WESTERHOFF P (2003) Biosorption of humic and fulvic acids to live activated sludge biomass. Water Res. 37 (10) 2301-2310.

GUELLIL A, THOMAS F, BLOCKJ-C BERSILLON JL and GINESTET P (2001) Transfer of organic matter between wastewater and activated sludge flocs. Water Res. 35 (1) 143-150.

HIRAOKA M, TAKEDAN, SAKAI S and YASUDA A (1984) Highly efficient anaerobic digestion with thermal pretreatment. Water Sci. Technol. 17 529-539.

KENNEDY KJ, THIBAULT G and DROSTE RL (2007) Microwave enhanced digestion of aerobic SBR sludge. Water SA 33 (2) 261-270. http://www.wrc.org.za/downloads/watersa/2007/Apr\%2007/2043. pdf.

KUNZ P and WAGNER S (1994) Results and outlooks of investigations of sewage sludge disintegration - Ergebnisse und Perspektive aus Untersuchungen zur Klärschlammdesintegration. AWT Abwassertechnik, Heft 1. 
MÜLLER J (1996) Mechanical disintegration of sewage sludge - Mechanischer Klärschlammaufschluß-, Schriftenereihe "Berichte aus der Verfahrenstechnik" der Fakultät für Maschinenbau und Elektrotechnik der Universität Braunschweig. Shaker Verlag, Aachen, Germany.

MÜLLER J (2000) Disintegration as key-stop in sewage sludge treatment. Water Sci. Technol. 41 123-139.

SENTHIL KUMAR P and PANDIT AB (1999) Modelling hydrodynamic cavitation. Chem. Eng. Technol. 22 1017-1027.

SENTHIL KUMAR P, SIVA KUMAR M and PANDIT AB (2000) Experimental quantification of chemical effects of hydrodynamic cavitation. Chem. Eng. Sci. 55 1633-1639.
TCHOBANOGLOUS G, BURTON FL and STENSEL HD (2002) Wastewater Engineering Treatment and Reuse (4th edn.). Metcalf \& Eddy, Inc.

TIECHM A, NICKEL K and NEIS U (1997) The use of ultrasound to accelerate the anaerobic digestion of sewage sludge. Water Sci. Technol. 36 121-128.

VICHARE NP, GOGATE PR and PANDIT AB (2000) Optimization of hydrodynamic cavitation using a model reaction. Chem. Eng. Technol. 23 683-690/

WANG F, LU SH and JI M (2004) Components of release liquid from ultrasonic waste activated sludge disintegration. Ultrasonics Sonochem. 13 334-338. 